\title{
Evaluation of Agronomic Performance and Seed Oil Composition of 15 Sunflower Genotypes in South Madagascar
}

\author{
A. Calamai ${ }^{1}$, A. Masoni ${ }^{1}$, E. Palchetti ${ }^{1}$, C. Grassi ${ }^{1}$, L. Brilli ${ }^{2}$ \\ ${ }^{1}$ Department of Agrifood and Environmental Science (DISPAA), Florence, Italy \\ ${ }^{2}$ IBIMET-CNR, Florence, Italy \\ Email: alessandro.calamai@unifi.it, chiara.grassi@unifi.it, 1.brilli@ibimet.cnr.it, Alberto.masoni@unifi.it, enrico.palchetti@unifi.it
}

How to cite this paper: Calamai, A., Masoni, A., Palchetti, E., Grassi, C. and Brilli, L. (2018) Evaluation of Agronomic Performance and Seed Oil Composition of 15 Sunflower Genotypes in South Madagascar. Agricultural Sciences, 9, 1337-1353. https://doi.org/10.4236/as.2018.910093

Received: September 19, 2018

Accepted: October 28, 2018

Published: October 31, 2018

Copyright $\odot 2018$ by authors and Scientific Research Publishing Inc. This work is licensed under the Creative Commons Attribution International License (CC BY 4.0).

http://creativecommons.org/licenses/by/4.0/

\begin{abstract}
Sunflower (Helianthus annuus L.) is one of the world's most important oilseed crops together with oil palm (Elaeis guineensis Jacq.), soybean (Glycine $\max ($ L.) Merr.) and rapeseed (Brassica napus L.). Despite the $8.5 \%$ of world sunflower cultivation is found in Africa, just few studies on oil seed performances and their chemical composition were carried out in tropical countries, thus reducing the knowledge on the adaptability and performances of this crop in humid areas. In this study the agronomic performance, environmental adaptability, oilseed production and fatty acid composition of 15 sunflower varieties cultivated in two underexploited areas of the Plateau de l'Horombe in southern Madagascar were evaluated. Results of this study indicated that: 1) sunflower has well performed in sub-arid localities thanks to its adaptability to harsh conditions, with similar performances to those obtained in other worldwide countries; 2) the well-structured and fertile soil resulted to be the key driver of sunflower performances; 3 ) the most productive hybrids between the sites were PR63D82 (conventional typology) and Klarika for yield and oil content, respectively; 4) the oleic/linoleic ratio of both $\mathrm{HO}$ and conventional sunflowers was influenced by changes in temperature.
\end{abstract}

\section{Keywords}

Sunflower, Madagascar, Yield, Oil Content, Oil Quality, Fatty Acids Profiles

\section{Introduction}

Sunflower (Helianthus annuus L.) is one of the world's most important oilseed crops together with oil palm (Elaeis guineensis Jacq.), soybean (Glycine max (L.) 
Merr.) and rapeseed (Brassica napus L.). This crop is cultivated on a total of over 26 million hectares worldwide, mainly for its high seed oil content ( 44\%) [1] [2] [3]. Depending on the fatty acid (FA) oil profile, the sunflower oil can be used in several sectors such as agriculture, chemical and cosmetic industries, and biodiesel production [4] [5].

Generally the oil profile comprises approximately $90 \%$ unsaturated fatty acid (UFA), mainly oleic and linoleic, and up to $10 \%$ of saturated fatty acid (SFA), principally palmitic and stearic acid [1] [6]. Concerning oleic and linoleic acids, for the northern hemisphere it is well known that these compounds are inversely correlated [3] [1]. This relation, however, may change due to factors such as environmental conditions, genotype and their interaction, which contribute to highly influence the oil profile [7] [8]. In particular, environmental factors such as climate (air temperature, rainfall, soil water regime, intercepted solar radiation, etc.) and agriculture management can affect the grain filling phase, thus modifying the final oil profile [3] [8] [9] and yield [6].

Sunflower oil is considered a high quality oil because of being rich in monounsaturated fatty acid (MUFA) and polyunsaturated fatty acid (PUFA) [3] [10]. These acids are indeed indispensable for human health, playing a protective role for humans by reducing plasma cholesterol and the risk of cardiovascular disease [11] [12]. Also, sunflower seeds are essential for the human diet since they are full of vitamins (e.g. E, B1, B5, B6) and specific acids (chlorogenic and folic) [11]. However, vegetable oils rich in PUFA are susceptible to lipid oxidation, which can originate from cytotoxic and genotoxic compounds that negatively affect the nutritional value and shelf-life of food products [13].

At the end of the last century, new genotypes called High-Oleic sunflower (HO) with higher MUFA content were developed [14] and became available on the market [15]. A diet rich in MUFA provides similar benefits than those provided using conventional sunflower oil (PUFA), avoiding the problem of lipid oxidation in the food oil [10] [16]. Particularly, oil seeds from HO genotype have a greater oxidative stability than conventional oils, which is desirable in cooking applications, refining process and storage [3] [5]. Nowadays sunflower hybrids can be divided into two principal groups based on oleic acid content: 1) conventional sunflower (15.0\% - 50.9\% oleic acid) and 2) high-oleic sunflower (over $87.4 \%$ oleic acid) [15].

Despite the $8.5 \%$ of world sunflower cultivation is found in Africa [17], just few studies on oil seed performances and their chemical composition can be currently found in tropical areas [1] [2], since in many African countries, such as Madagascar, this crop is cultivated only in limited surfaces [17]. However, thanks to well-developed root system, allopathic potential for weed control, etc., [18] [19], its cultivation may be enclosure within agronomic rotation by farmers, with a consequent introduction of a product able to provide healthy nutritional compounds for locals.

Given the large number of genotypes currently present in the global market, 
the agronomic performance, environmental adaptability, oilseed production and fatty acid composition of 15 sunflower varieties cultivated in two underexploited areas of the Plateau de l'Horombe in southern Madagascar were assessed. Crop productive and quality performances among different genotypes (HO vs conventional sunflower) was analyzed using simple statistical correlations, whilst the oleic-linoleic acid composition and biosynthetic pathway were accounted by means of a Path Analysis.

\section{Materials and Methods}

\subsection{Study Area}

The field experiments were carried out over the Plateau de l'Horombe, in the southern part of Madagascar, in two areas named Andiolava $\left(22^{\circ} 29^{\prime} 40^{\prime \prime S}\right.$, $\left.45^{\circ} 38^{\prime} 45^{\prime \prime} \mathrm{E}\right)$ and Satrokala $\left(22^{\circ} 19^{\prime} 49^{\prime \prime}, 45^{\circ} 43^{\prime} 4\right.$ "E). Traditionally, this sub-arid tropical region has a bimodal climate characterized by two well-distinguished seasons: the wet season from November to March, and the dry season from April to October Meteorological data, calculated from the local weather station, indicated a cumulated precipitation of around $800 \mathrm{~mm}$ during the growing season and a total annual of $1400 \mathrm{~mm}$, which is consistent with long-term precipitation average [20]. The rainfall recorded during the growing cycle was highly representative of traditional rainfall recorded during the same long-term average growing season (1997-2012, $856 \mathrm{~mm})$.

The average annual temperature is $20^{\circ} \mathrm{C}$, with the average minimum air temperatures found in July $\left(12.9^{\circ} \mathrm{C}\right)$ and the average maximum $\left(30.4^{\circ} \mathrm{C}\right)$ in December. During the grain filling period, the average minimum temperature was recorded in March $\left(16.4^{\circ} \mathrm{C}\right)$. Air humidity is almost constant throughout the year (80\%). Solar radiation follows the rainfall and temperature patterns, with maximum and minimum values occurring during winter and summer, respectively.

Soil characteristics showed differences between the site in terms of texture, soil organic matter (SOM) content, $\mathrm{pH}$ and cation exchangeable capacity (Table 1). Andiolava, classified as sandy-clay-loam soil, is slight acid $(\mathrm{pH}=5.8)$, with an organic matter content of $1.33 \%$ and a cation exchangeable capacity of 3.40 meq/100g. Satrokala has a sandy-clay texture, higher acidity $(\mathrm{pH}=4.8)$, with very low organic matter $(0.89 \%)$ and a cation exchangeable capacity of 3.34 $\mathrm{meq} / 100 \mathrm{~g}$.

\subsection{Field Set Up and Practices}

Experimental material included 13 commercial sunflower hybrids (nine conventional, and four high-oleic sunflower genotypes) and 2 Tanzanian populations (Table 2). Specific crop characteristics such as length of cycle or oil seed profile were known only for commercial hybrids, whilst no information was available for the populations.

Fields trials were set up during the 2012-2013 agronomic season according to 
Table 1. Soil characterization of the two experimental sites.

\begin{tabular}{cccc}
\hline Data & Units & Satrokala & Andiolava \\
\hline Sand $(2-0.05 \mathrm{~mm})$ & $\%$ & 45.2 & 62.4 \\
Loam $(0.05-0.002 \mathrm{~mm})$ & $\%$ & 9.8 & 9 \\
Clay $(<0.002 \mathrm{~mm})$ & $\%$ & 45 & 28.6 \\
Fine sand $(0.05-0.10 \mathrm{~mm})$ & $\%$ & 3.1 & 3.8 \\
USDA Class & -- & $\mathrm{SC}^{*}$ & SCL $^{*}$ \\
pH & -- & 4.8 & 5.8 \\
EC (Acqueous extraction 2:1) & $\mathrm{dS} / \mathrm{m}$ & 0.023 & 0.027 \\
Organic matter & $\%$ & 0.89 & 1.33 \\
P Olsen $\left(\mathrm{P}_{2} \mathrm{O}_{5}\right)$ & $\mathrm{ppm}$ & 7 & 1 \\
Cation exchange capacity pH 7 & $\mathrm{meq} / 100 \mathrm{~g}$ & 3.34 & 3.40 \\
Ca exchangeable & $\mathrm{ppm}$ & 140 & 260 \\
Mg exchangeable & $\mathrm{ppm}$ & 28 & 68 \\
Na exchangeable & $\mathrm{ppm}$ & 21 & 23 \\
K exchangeable & $\mathrm{ppm}$ & 31 & 106 \\
Basic saturation & $\%$ & 32.9 & 65.9 \\
\hline
\end{tabular}

${ }^{\star} \mathrm{SC}=$ Sandy Clay, $\mathrm{SCL}=$ Sandy Clay Loam.

a randomized block design with four replicates for each site (Andiolava and Satrokala). Then, 15 plots were arranged in each $6 \times 4 \mathrm{~m}$ block with a planting density of $6.8 \mathrm{plant} / \mathrm{m}^{2}$.

The seed-bed was prepared using a spike-tooth harrow (30 - $35 \mathrm{~cm}$ depth) followed by a disc-harrow (10 cm depth) before the seeding (December 2012). Fertilization was applied at a seed-bed time using $500 \mathrm{~kg} / \mathrm{ha}$ of NPK (11:22:16) and in January 2013 using Urea $(46 \% \mathrm{~N})$ in a dose of $100 \mathrm{Kg} / \mathrm{ha}$. Sowing was done in December 2012 when minimum soil temperature was 13 degrees [21]. Harvest was done at the end of April (2013) when plants turned bracts in the capitula into brown color [22]. Achenes collected were dried, cleaned by broken seeds and impurities and finally (i.e. $200 \mathrm{~g}$ from each test) analyzed.

\subsection{Data Collection}

The different phenological phases were monitored during the trials, following the methodology proposed in by [23] (Schneiter and Miller, 1981). During the growing stages the following parameters were collected analyzing five plants randomly chosen on each plot: plant height $(\mathrm{cm})$, stem diameter $(\mathrm{mm})$, leaves per plant and at harvest time also the plant dry weight (g) capitula diameter $(\mathrm{cm})$, seeds number and weight per capitula (g) (Table S1). Finally, data about total yield and biomass ( $\mathrm{t} / \mathrm{ha}$ ) and the 1000 seeds weight $(\mathrm{g})$ were collected from each plot (Table 2). 


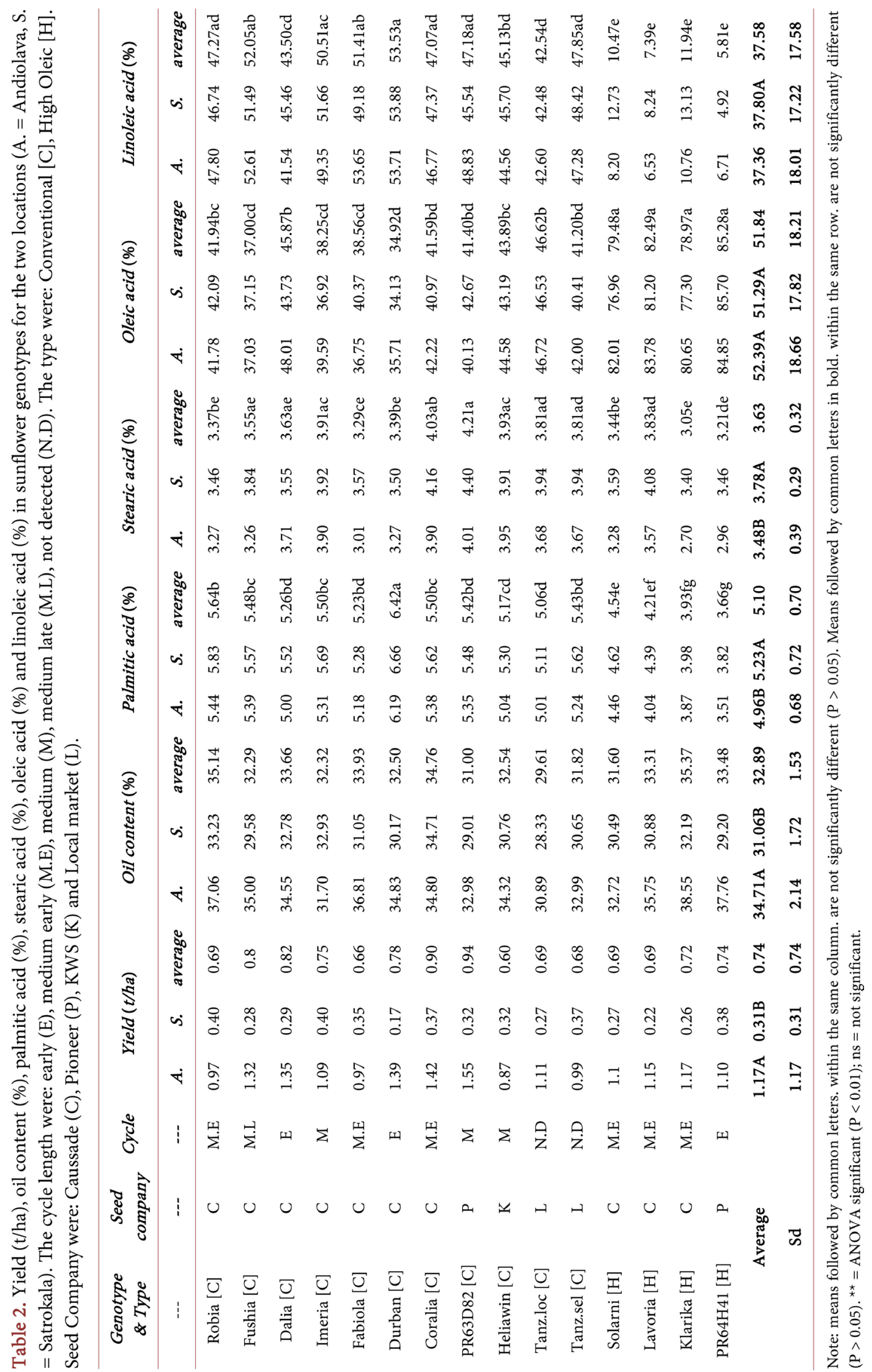




\subsection{Oil Analysis}

Seeds subsamples from each block of the same experimental site were mixed together and pressed for oil extraction using a mechanical press (IBG Monforts Oekotec GmbH\&Co, CA 59G-2008). The extracted oil, expressed as a weight percent relative to the initial weight of sunflower seeds, was maintained in a drying oven at $105^{\circ} \mathrm{C}$ for one hour. A specific amount of oil (i.e. $10 \mathrm{~g}$ ) was soaked with 0.3 methanol-sodium methylate and then held at $90^{\circ} \mathrm{C}$ for $2 \mathrm{~h}$ to convert the Fatty Acids (FA) into its methyl derivatives (Fatty acid methyl esters, FAME). Oil fatty acid composition was determined using Shimadzu GC-FID (model GC2010 Plus), equipped with a capillary column (wax-58 CB) and flame ionizing detector. FAME was identified by comparing retention times with those of well-known commercial standards and quantified as a relative percentage area.

\subsection{Statistical Analysis}

Morphological and productive traits were analyzed with a generalized linear mixed model (GLMM) with localities as random factor using the software IBM SPSS Statistics v.25 [24]. Multiple comparisons between genotypes were carried out using Tukey test. The correlation between all the collected variables was assessed using a Person correlation model implemented in the same software. In addition, the Principal Component Analysis (PCA) on oil FA composition, vegetative and productive traits were carried out with the software R [25]. Finally, the oleic acid biosynthetic pathway of both high oleic and conventional sunflower plants were investigated performing a path analysis (PA) [26] on the FA content in order to evaluate the direct and indirect effect of oil composition, tropical environment and genotypes. We firstly hypothesized an input path diagram with the oleic acid as dependent variables and linoleic, stearic and palmitic acids as independent ones. Then we carried out a multiple regression model between the dependent and independent variables to evaluate the path coefficients, that are the standardized $\beta$ weights of the regression analyses. These coefficients are important for path analysis because they represent the direct impact of an independent variable on dependent ones. A correlation analysis between the independent variables was performed to evaluate and explain their reciprocal effect. All these coefficients were then put in the hypothesized input path diagram to explain the connection between variables and finally convalidate an output path diagram. All analysis was carried out with SPSS software.

\section{Results}

\subsection{Biomass and Yield}

Analysis of variance allowed a general understanding of the productive and morphological response to locality and genotype (Table 3). For productive data, yield and total biomass resulted to be statistically affected by locality and the 
Table 3. Analysis of variance for productive, morphological and quality parameters.

\begin{tabular}{|c|c|c|c|c|c|c|c|c|c|c|c|c|c|c|c|}
\hline \multicolumn{16}{|c|}{ Productive } \\
\hline $\begin{array}{l}\text { Source of } \\
\text { Variation }\end{array}$ & D.o.F. & $\begin{array}{l}\text { Yield } \\
(\mathrm{t} / \mathrm{ha})\end{array}$ & $\begin{array}{c}\text { Total } \\
\text { Biomass } \\
\text { (t/ha) }\end{array}$ & $\begin{array}{l}1000 \text { seeds } \\
\text { weight }(\mathrm{g})\end{array}$ & & & & & & & & & & & \\
\hline Locality (L) & 1 & $* *$ & $* *$ & n.s. & & & & & & & & & & & \\
\hline error (a) & 6 & & & & & & & & & & & & & & \\
\hline Genotype (G) & 14 & n.s. & n.s. & $* *$ & & & & & & & & & & & \\
\hline$(\mathrm{L} \times \mathrm{G})$ & 14 & $* *$ & ** & n.s. & & & & & & & & & & & \\
\hline error (b) & 84 & & & & & & & & & & & & & & \\
\hline Total & 119 & & & & & & & & & & & & & & \\
\hline \multicolumn{16}{|c|}{ Morphological } \\
\hline $\begin{array}{l}\text { Source of } \\
\text { variation }\end{array}$ & D.o.F. & $\begin{array}{c}\text { Plant dry } \\
\text { weight (g) }\end{array}$ & $\begin{array}{l}\text { Plant } \\
\text { height } \\
(\mathrm{cm})\end{array}$ & $\begin{array}{l}\text { Leaves per } \\
\text { plant (n) }\end{array}$ & $\begin{array}{c}\text { Stem } \\
\text { diameter } \\
(\mathrm{mm})\end{array}$ & $\begin{array}{l}\text { Capitula } \\
\text { diameter } \\
(\mathrm{cm})\end{array}$ & $\begin{array}{l}\text { Seeds } \\
\text { per } \\
\text { capitula } \\
\text { (n) }\end{array}$ & $\begin{array}{l}\text { Seeds } \\
\text { per } \\
\text { capitula } \\
\text { (g) }\end{array}$ & & & & & & & \\
\hline Locality (L) & 1 & ** & ** & ** & ** & ** & ** & $* *$ & & & & & & & \\
\hline error (a) & 6 & & & & & & & & & & & & & & \\
\hline Genotype (G) & 14 & n.s. & $* *$ & * & $* *$ & n.s. & n.s. & n.s. & & & & & & & \\
\hline$(\mathrm{L} \times \mathrm{G})$ & 14 & $* *$ & $* *$ & $* *$ & n.s. & ** & ** & $* *$ & & & & & & & \\
\hline error (b) & 564 & & & & & & & & & & & & & & \\
\hline Total & 593 & & & & & & & & & & & & & & \\
\hline \multicolumn{16}{|c|}{ Quality } \\
\hline $\begin{array}{l}\text { Source of } \\
\text { variation }\end{array}$ & D.o.F. & $\begin{array}{c}\text { Oil } \\
\text { content }(\%)\end{array}$ & \multicolumn{13}{|c|}{ Fatty Acid Composition (\%) } \\
\hline & & & $14: 0$ & $16: 0$ & $16: 1$ & $17: 0$ & $18: 0$ & 18:1 & $18: 2$ & $18: 3$ & 20:0 & $20: 1$ & 22:0 & $22: 1$ & $24: 0$ \\
\hline Locality & 1 & $* *$ & $* *$ & $* *$ & $* *$ & * & $* *$ & n.s. & n.s. & $* *$ & $* *$ & n.s. & * & n.s. & n.s. \\
\hline Genotype & 14 & n.s. & $* *$ & $* *$ & $* *$ & n.s. & $* *$ & $* *$ & $* *$ & $* *$ & $* *$ & $* *$ & $* *$ & n.s. & n.s. \\
\hline error & 14 & & & & & & & & & & & & & & \\
\hline Total & 29 & & & & & & & & & & & & & & \\
\hline
\end{tabular}

The fatty acids identified in the sunflower oil were: myristic (14:0). palmitic (16:0). palmitoleic (16:1). margaric (17:0). stearic (18:0). oleic (18:1). linoleic (18:2). linolenic (18:3). arachidic (20:0). gondoic (20:1). behenic (22:0). erucic (22:1) and lignoceric $(24: 0)$ acids. ${ }^{*}=$ ANOVA significant $(\mathrm{P}<0.01)$; ${ }^{*}=$ ANOVA significant $(\mathrm{P}<0.05)$; ns $=$ not significant.

interaction between locality $\mathrm{x}$ genotype $(\mathrm{p}<0.01)$, while 1000 seeds weight showed high statistical significance only to genotype. Concerning vegetation data, the growth environment actively influenced all plant characteristics (locality for all variables $p<0.01)$. Genotype controlled only some parameters of plant morphology as plant high $(\mathrm{p}<0.01)$, number of leaves $(\mathrm{p}<0.05)$ and stem diameter $(p<0.01)$, while interaction between genotype and environment was statistically significant for all characters $(\mathrm{p}<0.01)$ but not for stem diameter $(\mathrm{p}>$ $0.05)$. 
Yields showed higher performances at Andiolava (1.17 t/ha, on average) compared to Satrokala ( $0.31 \mathrm{t} / \mathrm{ha}$, on average). At Andiolava yields ranged from 0.87 to $1.55 \mathrm{t} / \mathrm{ha}$, whilst at Satrokala they varied from 0.22 to $0.40 \mathrm{t} / \mathrm{ha}$ (Table 2). Between the sites, the most productive hybrid was PR63D82 (0.94 t/ha), while the less productive was Heliawin $(0.60 \mathrm{t} / \mathrm{ha})$, both belonging to conventional group. Globally, the average yield from conventional hybrids was $0.77 \mathrm{t} / \mathrm{ha}$ whilst that from $\mathrm{HO}$ hybrid was $0.71 \mathrm{t} / \mathrm{ha}$.

\subsection{Oil Quality}

The 13 different FA showed a carbon structure from C14 (myristic acid) to C24 (lignoceric acid) (Table S2). Oil content was affected only by locality $(\mathrm{p}<0.01)$. More specifically, oleic, linoleic and gondoic acids showed high statistical significance only to genotype ( $\mathrm{p}<0.01$ ); margaric acid was influenced only by locality $(\mathrm{p}<0.05)$, whilst myristic, palmitic, palmitoleic, linolenic, arachidic and behenic acids were influenced by both locality and genotype. For the remaining acids (i.e. erucic and lignoceric acids), none statistical significance has been found.

The average oil content ranged from $34.7 \%$ at Andiolava to $31.06 \%$ at Satrokala (Table 2). In particular, in the first locality all genotype exceeded $30 \%$ of oil percentage with the highest values $38.6 \%$ observed in Klarika hybrid and the lowest in Tanzania local population (30.9\%). Regarding Satrokala, Coralia hybrid showed the best results with $34.7 \%$ of oil concentration and Tanzania local the lowest, which not exceed the $30 \%$ threshold. Palmitic, stearic, oleic and linoleic acids were also reported more in detail since they globally constitute the $98.1 \% \pm$ $0.4 \%$ of the total oil fatty acid composition (Table 2 ). Overall, no great differences were found between the sites, with average higher values for palmitic, stearic and linoleic acids at Satrokala and for oleic acid at Andiolava. Looking at the different genotypes, the average highest palmitic and stearic acids were found in Durban (6.42\%) and PR63D82 (4.21\%). The oleic acid showed the highest content in PR64H41 (85.28\%) and generally in all HO hybrids, which showed an oil content almost two times greater than conventional. Linoleic acid showed the average highest content in Durban (53.53\%) and generally in all conventional group.

\subsection{PCA and Correlation Analysis}

The results of PCA were graphically represented in a two-dimensional plot (Figure 1). The first two components explained more than $60 \%$ of the variability between the samples. Genotypes were clearly subdivided into two groups depending on the environment which considerably influenced the morphological and productive traits. Within the same group the HO hybrids were separated from the conventional, and Tanzanian genotype mainly for their high concentration in oleic, gadoleic and lignoceric acids.

Positive correlations were found between yield and oil content for all morphological data. The relationships between productive variables and fatty acids 


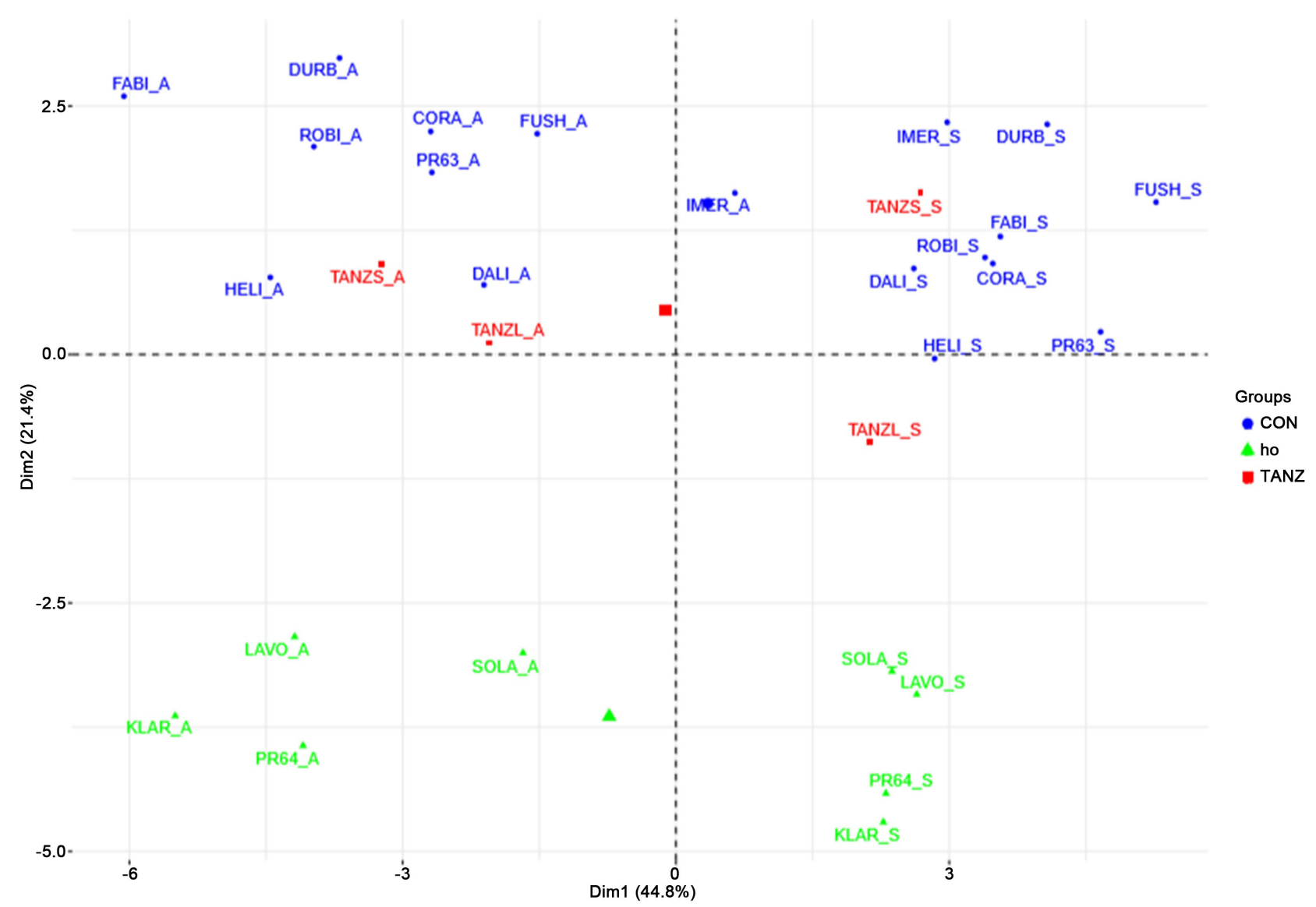

Figure 1. Combined plot of 15 sunflower varieties replicated in the two sowing areas (30 samples) on the first two principal components retaining $65 \%$ of multivariate variability.

indicated a negative correlation for margaric, stearic, linolenic and arachidic acids. A negative correlation was also found between 1000 seeds weight to myristic and palmitoleic acids. Oleic acid was found negatively correlated with linoleic ( $\mathrm{r}$ $=-0.995)$, palmitic $(\mathrm{r}=-0.904)$ and myristic $(\mathrm{r}=-0.728)$ acids, but positively correlated with gondoic $(r=0.892)$, behenic $(r=0.739)$ and lignoceric acids $(r=$ 0.580). Linoleic acid was negatively linked to oleic $(r=-0.995)$, gondoic $(r=$ $-0.885)$, behenic $(r=-0.749)$ and lignoceric acids $(r=-0.582)$, whereas a positive correlation was found with palmitic $(\mathrm{r}=0.894)$ and myristic $(\mathrm{r}=0.719)$ acids.

Stearic acid was also negatively correlated to gondoic $(\mathrm{r}=-0.584)$, but positively with arachidic $(r=0.722)$ and margaric $(r=0.452)$ acids.

Path coefficient was calculated to obtain further information about the relation between oleic acid content and the other FA engaged in its biosynthetic pathway (Figure 2). Analysis has been carried out separately for HO and conventional genotypes. Results indicated that $\mathrm{HO}$ genotypes showed a negative relation between oleic and linoleic acid $(-0.941)$, very close to that found for conventional (-0.975). Finally, stearic and palmitic acid were negatively correlated with oleic acids both in $\mathrm{HO}$ and conventional genotypes. 


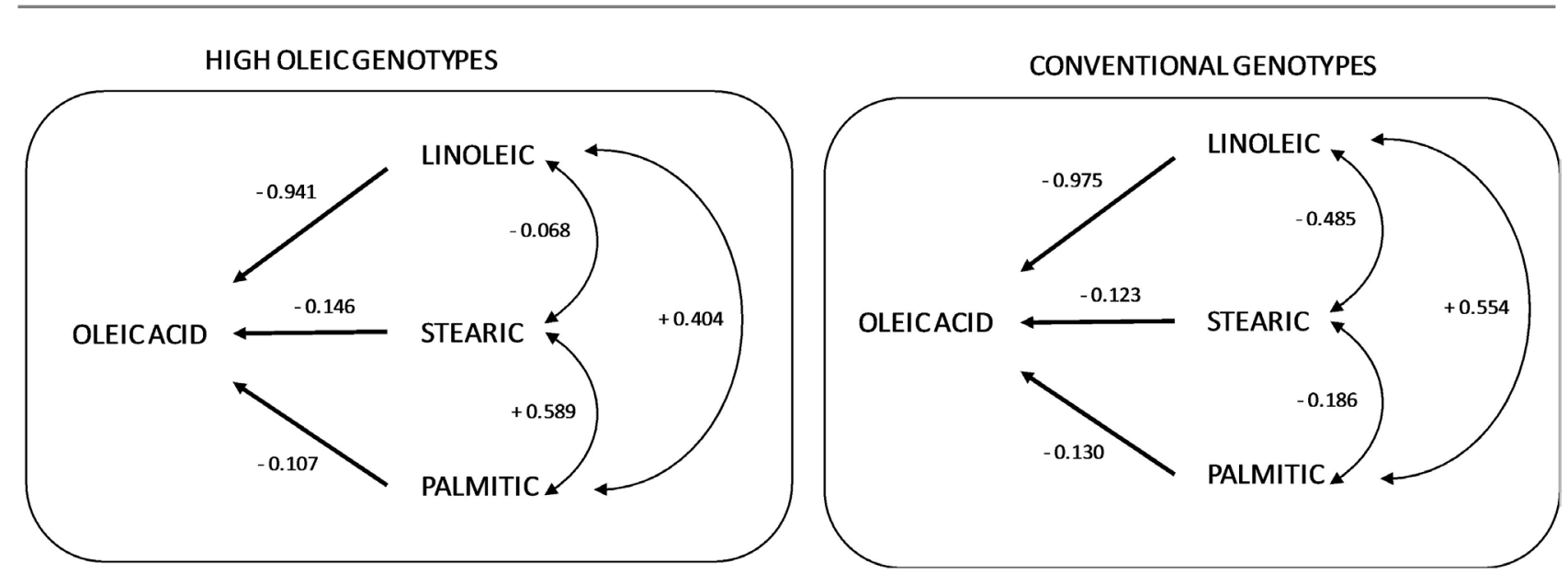

Figure 2. Oleic and linoleic path analysis pathway divided by genotypes. On the straight arrow are reported the path coefficients, on the curve arrow the correlations coefficients.

\section{Discussion}

In this study the agronomical performances, yields and oil content of 13 hybrids and 2 varieties of sunflower cultivated in two different areas of southern Madagascar were investigated. Firstly emerged as the different characteristics of the two study areas strongly affected crop performances. Morphological parameters resulted to be mainly influenced by soil characteristics such as texture, $\mathrm{pH}$ and fertility. The high influence of soil characteristics on sunflower performances was partly expected since several studies indicated that even in different climatic areas they play the key role on vegetative performances [3] [27] [28]. The soil characteristics at Andiolava likely favored plant growth and development, strongly increasing the sunflower biomass. In particular, the higher SOM content at Andiolava may have improved soil physical properties such as texture, structure, bulk density as well as soil nutrient availability, thus favoring the plant growth and dry matter accumulation [29]. Another key aspect was the soil pH. More specifically, whilst the $\mathrm{pH}$ found at Andiolava was close to the optimum (6.0 - 7.5) reported for sunflower [30], at Satrokala the lower $\mathrm{pH}$ may have inhibited root growth and development, consequently reducing the nutrients absorption. This agree with [31] (Tang et al., 2003), which indicated as a limited capacity in root-soil exploring can increase the risk of nutrient deficiency and directly decrease sunflower yield. The different averaged yields between Andiolava ( $1.17 \mathrm{t} / \mathrm{ha})$ and Satrokala $(0.31 \mathrm{t} / \mathrm{ha})$ suggested as fertile Madagascar soils can allow a yield production similar to that found in other African nations (e.g. Nigeria, $\sim 1.00 \mathrm{t} / \mathrm{ha})$, consistently higher than African mean production (0.81 $\mathrm{t} / \mathrm{ha}$ ), and not too far from the world average level (1.52 t/ha) [2] [32] [33].

Looking at oil production, the oil content in the two sites ranged from $31 \%$ to $34.7 \%$. These values agree with those found by [34] (Neto et al., 2016) and [35] (Oshundiya et al., 2014) in humid tropics, thus suggesting as the environment was the major factor contributing to the final seed oil accumulation. On the contrary, genotype was the main factor influencing the FA composition, as con- 
firmed also by the finding from [36] (Van Der Merwe et al., 2013), which compared three different sunflower types (i.e. conventional, mid- and high-oleic) in South Africa. Similar results were reported also by [27] (Salera and Baldini, 1998), which analyzed conventional and high oleic sunflower in four different sites in Italy. The little influence of the environment in FA composition is frequently reported in literature especially for HO genotypes, where the oleic and linoleic acid contents are less affected than in standard genotypes [1] [3]. This was probably due to a specific gene that increases oleic acid stability as observed by several studies [27] [37] [38]. Globally, the correlations found in this study reflected those highlighted in other countries such as Nigeria [39], South Africa [36], Brasil [34], Argentina [15], and Italy [3], and confirmed the biosynthesis mechanism of FA proceeds in seed storage lipids as reported by [40] (Voelker and Kinney, 2001).

The HO genotypes confirmed their capacity to accumulate oleic acid also in tropical environments, thus showing a large negative regression between oleic and linoleic acids, as observed by [41] (Roche et al., 2004). Looking at PA results, the major differences between $\mathrm{HO}$ and conventional genotypes concerned stearic and palmitic acids: the positive correlation between the two FA in the $\mathrm{HO}$ genotypes compared to the conventional may suggest that the interruption of the synthesis of linoleic acid in the HO genotypes can lead to an increase of stearic acid contents and, as a consequence, of the palmitic acid. This dynamic can indicate that a feedback process may occur with the interruption of the metabolic synthesis of linoleic acid in the HO genotypes, leading to an increase of stearic and palmitic acids compared to that found in conventional genotypes.

The oleic acid percentage observed in conventional sunflowers as Dalia (45.87\%) and Tanzania local (46.62\%) were higher than their possible range of 14\% - 39.4\% suggested by Codex Alimentarius Committee [42]. This condition was observed also in Brazil [1] and Argentina [15], where the climatic conditions observed during grain filling were similar to those found in this study. This was probably due to the effect of minimum night temperatures during the achene grain filling that may have influenced the activity of oleate desaturase, an enzyme needed to convert oleic to linoleic acid [3]. This dynamic was observed by [7] (Steer and Seiler, 1990), which showed that the synthesis or activation of desaturase enzyme can be stimulated by low temperature either repressed by high temperature.

The findings of this study pose also questions on the nutritional role that this crop may play in undernourished countries such as Madagascar. In this country, the average vegetable oil consumption is estimated to be $1.96 \mathrm{~kg} /$ year per capita [43], which result to be very far from the average global consumption of 24 $\mathrm{kg} /$ year per capita [44]. The main vegetable oils used in the Malagasian diet were soybean, palm, coconut and peanut oil. Some of these (palm and coconut), however, are recognized to be rich in saturated fatty acid that may increase the occurrence of some cardiovascular and heart diseases [45] [46]. Consequently, 
the increasing of the consumption of vegetable oils with a higher level of unsaturated FA such as sunflower oil in that areas may lead advantages from a nutritional point of view besides to be implemented within agronomic rotation as substitute of the most traditional oilseed crop such as groundnut and palm [47].

\section{Conclusions}

The studies of sunflower cultivation in tropical areas are quite lacking since mostly lands are used for staple food crop. This lacking, however, strongly reduced the understanding of sunflower biomass and oil production performances as well as the knowledge on possible chemical changes in oil seed due to climate or soil characteristics in tropical areas. To our knowledge, this is one of the few studies which assessed the agronomic performance, environmental adaptability, oilseed production and fatty acid composition of sunflower by comparing 15 different varieties in a tropical environment such as Madagascar. Results of this study indicated that: 1) sunflower has well performed in sub-arid localities thanks to its adaptability to harsh conditions, with similar performances to those obtained in other worldwide countries; 2) the well-structured and fertile soil, resulted to be the key driver of sunflower performances; 3 ) the most productive hybrids between the sites were PR63D82 (conventional typology) and Klarika for yield and oil content, respectively; 4) the oleic/linoleic ratio of both $\mathrm{HO}$ and conventional sunflowers was influenced by changes in temperature.

These results should be considered as a first step to improve the knowledge and use of sunflower in Madagascar. Information retrievable from this study can indeed encourage changes in local market perspectives beside to provide suggestions to local farmers for choosing the best genotypes for any specific cultivation areas. The spreading of sunflower cultivation may also allow increasing the consumption of healthy vegetable oils compared to those currently used in Madagascar. However, further researches are needed to fill the gap of the sunflower response in tropical countries compared to the US or Europe.

\section{Acknowledgements}

The authors would like to thanks the Company Tozzi Green S.a.r.l. based in Madagascar for the financial support to the research and for providing the personnel involved in the field trials.

\section{Conflicts of Interest}

The authors declare no conflicts of interest regarding the publication of this paper.

\section{References}

[1] Grunvald, A.K., Carvalho, C.G.P., Leite, R.S., Mandarino, J.M.G., Andrade, C.A.D., Amabile, R.F. and Godinho, V.D.C. (2013) Influence of Temperature on the Fatty Acid Composition of the Oil from Sunflower Genotypes Grown in Tropical Regions. Journal of the American Oil Chemists Society, 90, 545-553. 
https://doi.org/10.1007/s11746-012-2188-6

[2] Olowe, V.I., Folarin, O.M., Adeniregun, O., Atayese, M.O. and Adekunle, Y.A. (2013) Seed Yield, Head Characteristics and Oil Content in Sunflower Varieties as Influenced by Seeds from Single and Multiple Headed Plants under Humid Tropical Conditions. Annals of Applied Biology, 163, 394-402.

https://doi.org/10.1111/aab.12064

[3] Flagella, Z., Rotunno, T., Tarantino, E., Di Caterina, R. and De Caro, A. (2002) Changes in Seed Yield and Oil Fatty Acid Composition of High Oleic Sunflower (Helianthus annuus L.) Hybrids in Relation to the Sowing Date and the Water Regime. European Journal of Agronomy, 17, 221-230. https://doi.org/10.1016/S1161-0301(02)00012-6

[4] Burton, J.W., Miller, J.F., Vick, B.A., Scarth, R. and Holbrook, C.C. (2004) Altering Fatty Acid Composition in Oil Seed Crops. Advances in Agronomy, 84, 273-306. https://doi.org/10.1016/S0065-2113(04)84006-9

[5] Zheljazkov, V.D., Vick, B.A., Baldwin, B.S., Buehring, N., Coker, C., Astatkie, T. and Johnson, B. (2011) Oil Productivity and Composition of Sunflower as a Function of Hybrid and Planting Date. Industrial Crops and Products, 33, 537-543. https://doi.org/10.1016/j.indcrop.2010.11.004

[6] Andrianasolo, F.N., Casadebaig, P., Maza, E., Champolivier, L. and Maury, P. (2014) Prediction of Sunflower Grain Oil Concentration as a Function of Variety, Crop Management and Environment Using Statistical Models. European Journal of Agronomy, 54, 84-96. https://doi.org/10.1016/j.eja.2013.12.002

[7] Steer, B.T. and Seiler, G.J. (1990) Changes in Fatty Acid Composition of Sunflower (Helianthus annuus L.) Seeds in Response to Time of Nitrogen Application, Supply Rates and Defoliation. Journal of the Science of Food and Agriculture, 51, 11-26. https://doi.org/10.1002/jsfa.2740510103

[8] Echarte, M.M., Pereyra-Irujo, P.I., Covi, M., Izquierdo, N.G. and Aguirrezabal, L.A.N. (2010) Producing Better Sunflower Oils in a Changing Environment. In: Advances in Fats and Oil Research, Transworld Research Network Mabel Cristina Tomás, Argentina, 1-23.

[9] Baldini, M., Giovanardi, R., Tahmasebi-Enferadi, S. and Vannozi, G. (2003) Effects of Water Regime on Fatty Acid Accumulation and Final Fatty Acid Composition in the Oil of Standard and High Oleic Sunflower Hybrids. Italian Journal of Agrono$m y$, 6, 119-126.

[10] Miller, J.F., Zimmerman, D.C. and Vick, B.A. (1987) Genetic Control of High Oleic Acid Content in Sunflower Oil. Crop Science, 27, 923-926. https://doi.org/10.2135/cropsci1987.0011183X002700050019x

[11] Pal, D. (2011) Sunflower (Helianthus annuus L.) Seeds in Health and Nutrition. In: Nuts and Seeds in Health and Disease Prevention, 1097-1105. https://doi.org/10.1016/B978-0-12-375688-6.10130-6

[12] Celus, M., Salvia-Trujillo, L., Kyomugasho, C., IneMaes, I., Van Loey, A.M., Grauwet, T. and Hendrickx, M.E. (2018) Structurally Modified Pectin for Targeted Lipid Antioxidant Capacity in Linseed/Sunflower Oil-in-Water Emulsions. Food Chemistry, 241, 86-96. https://doi.org/10.1016/j.foodchem.2017.08.056

[13] Kanner, J. (2007) Dietary Advanced Lipid Oxidation Endproducts Are Risk Factors to Human Health. Molecular Nutrition and Food Research, 51, 1094-1101. https://doi.org/10.1002/mnfr.200600303

[14] Soldatov, K.I. (1976) Chemical Mutagenesis in Sunflower Breeding. International 
Sunflower Conference, Proceedings of the Paris International Sunflower Association, Krasnodar, 352-357.

[15] Alberio, C., Izquierdo, G.N., Galella, T., Zuil, S., Reid, R., Zambelli, A. and Aguirrezábal, L.A.N. (2016) A New Sunflower High Oleic Mutation Confers Stable oil Grain Fatty Acid Composition across Environments. European Journal of Agrono$m y, 73,25-33$. https://doi.org/10.1016/j.eja.2015.10.003

[16] Delpanque, B. (2000) Intéret nutritionnel des tournesols. Proceedings of 15 th International Sunflower Conference, Toulouse, Vol. 1, PIB15-16.

[17] FAOSTAT (2016) Food and Agriculture Organization of the United Nations. http://www.fao.org/faostat/en/\#data/QC

[18] Angadi, S.V. and Entz, M.H. (2002) Root System and Water Use Patterns of Different Height Sunflower Cultivars. Agronomy Journal, 94, 136-145. https://doi.org/10.2134/agronj2002.0136

[19] Stone, L.R., Goodrum, D.E., Schlegel, A.J., Jaafar, M.N. and Khan, A.H. (2002) Water Depletion Depth of Grain Sorghum and Sunflower in the Central High Plains. Agronomy Journal, 94, 936-943. https://doi.org/10.2134/agronj2002.9360

[20] World Bank (2018). http://sdwebx.worldbank.org/climateportal/index.cfm?page=country_historical_cli $\underline{\text { mate } \& \text { ThisCCode }=\text { MDG }}$

[21] Dubetz, S., Russell, G.C. and Anderson, D.T. (1962) Effect of Soil Temperature on Seedling Emergence. Canadian Journal of Plant Science, 42, 481-487. https://doi.org/10.4141/cjps62-076

[22] Farizo, C.L., Pereyra, V.R., Cardinali, F. and Orioli, G. (1982) Determination of Physiological and Harvest Maturity in Sunflower. 10th International Sunflower Conference Surfers Paradise, 14-18 March 1982, 42-44.

[23] Schneiter, A. and Miller, J.F. (1981) Description of Sunflower Growth Stages. Crop Science, 21, 901-903. https://doi.org/10.2135/cropsci1981.0011183X002100060024x

[24] IBM Corp. (2017) IBM SPSS Statistics for Windows, Version 25.0. IBM Corp., Armonk.

[25] https://www.r-project.org/

[26] Dewey, D.R. and Lu, K.H. (1959) A Correlation and Path-Coefficient Analysis of Components of Crested Wheatgrass Seed Production. Agronomy Journal, 51, 515-518. https://doi.org/10.2134/agronj1959.00021962005100090002x

[27] Salera, E. and Baldini, M. (1998) Performance of High and Low Oleic Acid Hybrids of Sunflower under Different Environmental Conditions. Note II. Helia, 21, 55-68.

[28] Sutradhar, A.P., Lollato, R.P., Butchee, K. and Arnall, D.B. (2014) Determining Critical Soil $\mathrm{pH}$ for Sunflower Production. International Journal of Agronomy, 2014, Article ID: 894196. https://doi.org/10.1155/2014/894196

[29] Fageria, N.K. (2012) Role of Soil Organic Matter in Maintaining Sustainability of Cropping Systems. Communications in Soil Science and Plant Analysis, 43, 2063-2113. https://doi.org/10.1080/00103624.2012.697234

[30] Berglund, D.R. (2007) Sunflower Production, North Dakota Agricultural Experiment Station and North Dakota State University Extension Service Extension Publication A-1331 (EB-25 Revised). North Dakota State University, Fargo.

[31] Tang, C., Rengel, Z., Diatloff, E. and Gazey, C. (2003) Responses of Wheat and Barley to Liming on a Sandy Soil with Subsoil Acidity. Field Crops Research, 80, 235-244. https://doi.org/10.1016/S0378-4290(02)00192-2 
[32] USDA (2012) United States Department of Agriculture Statistics on Oilseeds, Fats and Oils. http://www.nass.usda.gov/Publications/Ag_Statistics/2012/chapter03.pdf

[33] Conab (2015) Companhia Nacional de Abastecimento. Acompanhamento da safra brasileira de grãos v. 2 Safra 2014/15, n. 8 Oitavo Levantamento. Conab, Brasília, $118 \mathrm{p}$.

[34] Neto, A.R., de Oliveira Miguel, A.M.R., Mourad, A.L., Henriques, E.A. and Alves, R.M.V. (2016) Environmental Effect on Sunflower Oil Quality. Crop Breeding and Applied Biotechnology, 16, 197-204. https://doi.org/10.1590/1984-70332016v16n3a30

[35] Oshundiya, F.O., Olowe, V.I.O., Sowemimo, F.A. and Odedina, J.N. (2014) Seed Yield and Quality of Sunflower (Helianthus annuus L.) as Influenced by Staggered Sowing and Organic Fertilizer Application in the Humid Tropics.

[36] Van Der Merwe, R., Labuschagne, M.T., Herselman, L. and Hugo, A. (2013) Stability of Seed Oil Quality Traits in High and Mid-Oleic Acid Sunflower Hybrids. Euphytica, 193, 157-168. https://doi.org/10.1007/s10681-013-0888-0

[37] Lagravere, T., Lacombe, S., Surel, O., Kleiber, D., Berville, A. and Dayde, J. (2000) Oil Composition and Accumulation of Fatty Acids in New Oleic Sunflower ( $\mathrm{He}$ lianthus annuus L.). 15th International Sunflower Conference, Toulouse, 12-15 June 2000, Vol. 1, A.25-A.30.

[38] Piva, G., Bouniols, A. and Mondiès, M. (2000) Effect of Cultural Conditions on Yield, Oil Content and Fatty Acid Composition of Sunflower Kernel. 15th International Sunflower Conference, Toulouse, Tome I, A.61-A.66.

[39] Onemli, F. (2012) Impact of Climate Changes and Correlations on Oil Fatty Acids in Sunflower. Pakistan Journal of Agricultural Science, 49, 455-458.

[40] Voelker, T. and Kinney, A.J. (2001) Variations in the Biosynthesis of Seed Storage Lipids. Annual Review of Plant Physiology and Plant Molecular Biology, 52, 335-361. https://doi.org/10.1146/annurev.arplant.52.1.335

[41] Roche, J., Essahat, A., Bouniolis, A., El Asri, M., Mouloungui, Z., Mondiès, M. and Al-ghoum, M. (2004) Diversified Composition of Sunflower (Helianthus annuus L.) Seeds within Cultural Practices and Genotypes (Hybrids and Population). Helia, 27, 73-98. https://doi.org/10.2298/HEL0440073R

[42] Codex Alimentarius Committee (2005) Codex Standard for Named Vegetable Oils. Codex-Stan 210, 2. http://www.fao.org/docrep/004/y2774e/y2774e04.htm

[43] FAOSTAT (2012) Food and Agriculture Organization of the United Nations. http://www.fao.org/faostat/en/\#data/QC

[44] Jha, G.K., Pal, S., Mathur, V.C., Bisaria, G., Anbukkani, P., Burman, R.R. and Dubey, S.K. (2012) Edible Oilseeds Supply and Demand Scenario in India: Implications for Policy. Report of the Indian Agricultural Research Institute.

[45] Assuncao, M.L., Ferreira, H.S., Dos Santos, A.F., Cabral, C.R. and Florêncio, T.M. (2009) Effects of Dietary Coconut Oil on the Biochemical and Anthropometric Profiles of Women Presenting Abdominal Obesity. Lipids, 44, 593-601. https://doi.org/10.1007/s11745-009-3306-6

[46] Dorni, C., Sharma, P., Saikia, G. and Longvah, T. (2018) Fatty Acid Profile of Edible Oils and Fats Consumed in India. Food Chemistry, 238, 9-15. https://doi.org/10.1016/j.foodchem.2017.05.072

[47] Ogunreni, E.A. (2000) Sunflower, Kenaf and Sugar-Cane in Nigeria: My Experiences. In: Akoroda, M.O., Ed., Agronomy in Nigeria, University of Ibadan, Ibadan, 130-142. 


\section{Supplementary}

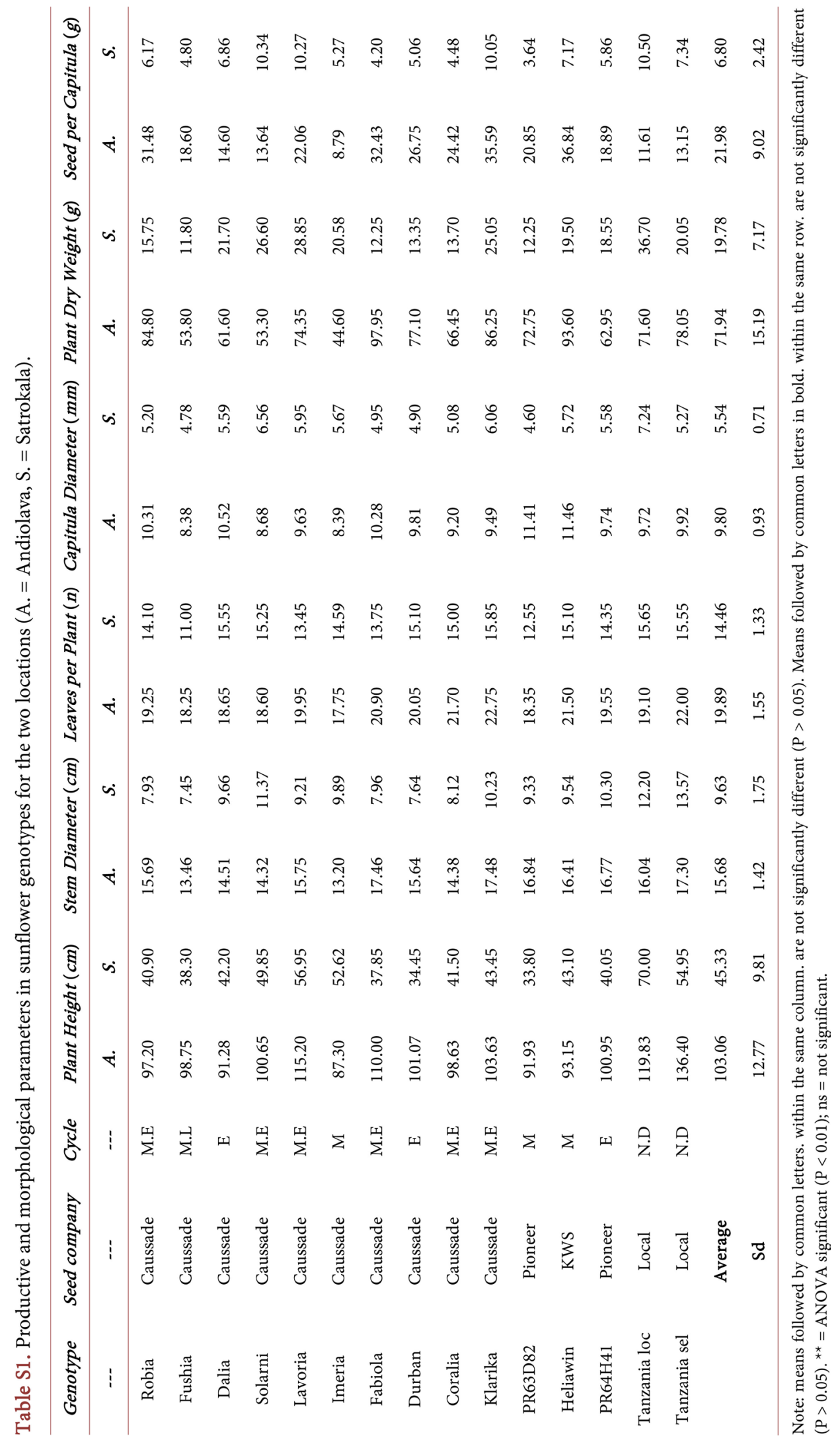




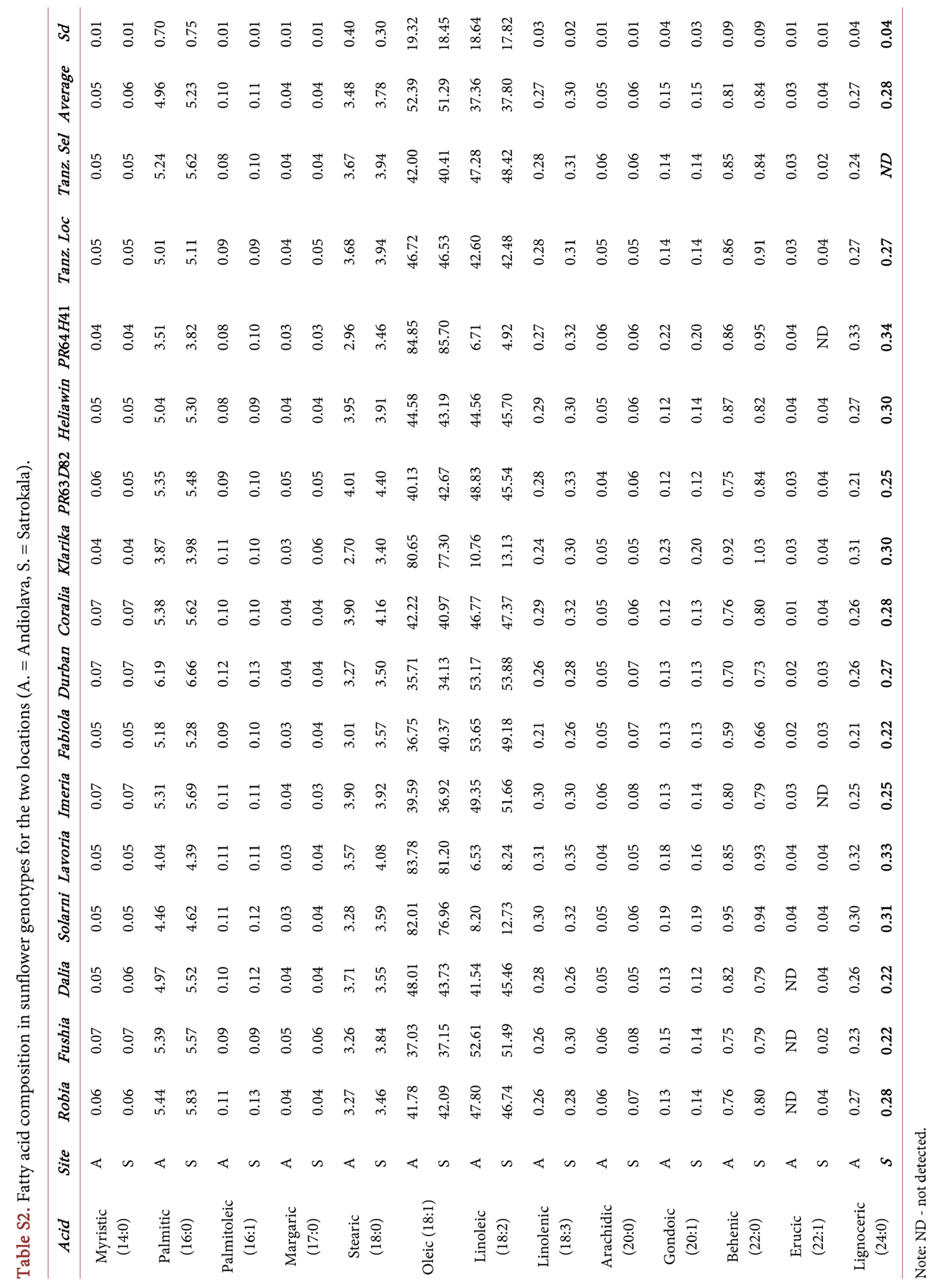

